\title{
ANALISIS TINGKAT PENGETAHUAN MASYARAKAT DESA SEI-PETAI TERHADAP PENYELENGGARAAN JENAZAH \\ KEC. KAMPAR KIRI HILIR KAB. KAMPAR
}

\author{
MIFYAH SYARIF \\ Universitas Islam Riau \\ Jl. Kaharuddin Nasution, No. 113, Perhentian Marpoyan Pekanbaru 28284 \\ e-mail: miftah_syarif@fis.uir.ac.id \\ ARY ANTONY PUTRA \\ Universitas Islam Riau \\ Jl. Kaharuddin Nasution, No. 113, Perhentian Marpoyan Pekanbaru 28284 \\ e-mail: aryantonyputra@fis.uir.ac.id

\section{MAWARDI AHMAD} \\ Universitas Islam Riau \\ Jl. Kaharuddin Nasution, No. 113, Perhentian Marpoyan Pekanbaru 28284 \\ e-mail: mawardiahmad@fis.uir.ac.id
}

\begin{abstract}
Abstrak : Jenis penelitian ini adalah diskriptif kuantitatif dengan fokus masalah pada Bagaimana Tingkat Pengetahuan masyarakat Desa Sungai Petai Kec. Kampar Kiri Hilir Kabupaten Kampar terhadap penyelenggaraan jenazah. Tujuan penelitian ini unutk mengetahui tingkat pengetahuan masyarakat Desa Sungai Petai Kec. Kampar Kiri Hilir Kabupaten Kampar terhadap penyelenggaraan jenazah. Subyek penelitian ini adalah masyarakat Desa Sei-Petai Kec. Kampar Kiri Hilir Kab. Kampar. Sedangkan obyeknya adalah Tingkat Pengetahuan masyarakat Desa Sei-Petai Kec. Kampar Kiri Hilir Kab. Kampar terhadap penyelenggaraan jenazah. Populasi yang diambil adalah masyarakat Muslim Desa Sei-Petai Kec. Kampar Kiri Hilir Kab. Kampar yang berjumlah 441 orang, sedangkan sampelnya 44 orang. Dari keseluruhan sampel yang mengembalikan angket sebanyak 31 orang. Teknik pengambilan data menggunakan angket dan dokumentasi. Pengolahan dan analisa data menggunakan metode analisis deskriptif kuantitatif yaitu data yang terkumpul diedit, dikelompokkan, dan ditabulasi, untuk kemudian diambil kesimpulan. Hasil penelitian ini menunjukkan bahwa Tingkat Pengetahuan Masyarakat Sungai Petai terhadap Penyelenggaraan Jenazah pada persentase 71,99\%, berada pada rentang 50\% - 79\%, yang dapat diartikan dalam kategori "Cukup Baik".
\end{abstract}

Kata kunci: Analisis, Tingkat Pengetahuan, Penyelenggaraan Jenazah

\section{PENDAHULUAN}

Manusia diciptakan oleh Allah SWT adalah sebagai "Khalifatullah" dan "Abdullah" guna dan tujuan untuk bisa mendekatkan diri kepada allah SWT. Dan manusia adalah makhluk yang sangat sempurna yang diciptakan dibandingkan dengan makhluk ciptaannya yang lain, Bahwa di dalam tubuh manusia didukung oleh dua unsur atau komponen, yaitu unsur yang bersipat fisik dan unsur metafisik (rohani dan spritual). fisik yang 
terdiri atas tubuh atau raga, sedangkan metafisik adalah unsur dalam dari manusia yang biasa disebut dengan ruh atau nafs (jiwa) (Muhammad Tholchah Hasan, 2004 : 97).

Dalam firman Allah SWT :

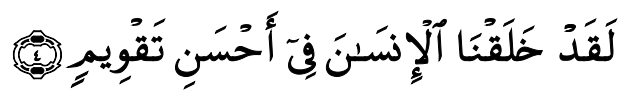

Artinya :Sesungguhnya kami

Telah menciptakan manusia dalam bentuk yang sebaik-baiknya. (QS. AtTiin, $95: 4$ ) (Al-qur'an dan terjemah, 2006 : 478).

Dengan kelebihan yang dimiliki tersebut manusia memiliki tugas, bisa juga disebut dengan tugas hidup manusia. semua aktifitas hidup harus sejalan dengan tujuan hidup yang ingin dicapai oleh manusia. Tidak boleh menghambat tercapainya tujuan hidup itu, apa lagi bertentangan atau menyimpang jauh (Abu Bakar Muhammad,1994 : 77).

Tugas pengabdian atau ibadah kepada Allah itu bukan hanya Shalat, Haji, Puasa dan Zakat atau ibadah-ibadah yang lain, tetapi beribadah memiliki arti yang sangat luas yang meliputi seluruh aktifitas hidup yang menjamin tercapainya kebahagiaan hidup yang hakiki dan abadi dalam surga di akhirat kelak. Jadi pengertian ibadah sebagai tugas hidup ini adalah sejalan dengan tugas manusia sebagai khalifah Allah di muka bumi ini. Untuk diketahui ada tiga tugas hidup manusia sebagai khalifah Allah di bumi ini yang dapat menjamin tercapainya tujuan hidup jangka pendek maupun tujuan hidup jangka panjang, yaitu : tugas terhadap dirinya sendiri, tugas terhadap keluarga dan rumah tangga, dan tugasnya dalam masyarakat, bangsa serta negara (Abu Bakar Muhammad,1994 : 81).

Maka dari tugas hidup inilah manusia harus memiliki ilmu dan wajib mendapatkan pendidikan, karena antara pendidikan dan kehidupan adalah dua hal yang identik yang tak terpisahkan, bagaikan air dengan ikannya. Berbicara tentang pendidikan berarti berbicara tentang hidup dan kehidupan manusia. Sebaliknya, berbicara tentang kehidupan manusia berarti harus mempersoalkan masalah pendidikan. Pepatah menyatakan bahwa sepanjang hidup adalah pendidikan (life long aducation). Kehidupan manusia adalah persoalan pendidikan (Suparlan Suhartono, 2012:62).

Pendidikan berlangsung di segala jenis, bentuk, dan tingkat lingkungan hidup, yang kemudian mendorong pertumbuhan segala potensi yang ada di dalam diri individu. Dengan kegiatan pembelajaran seperti itu, individu mampu mengubah dan mengembangkan diri menjadi semakin dewasa, cerdas, dan matang. Jadi singkatnya, pendidikan merupakan sistem proses perubahan menuju pendewasaan, pencerdasan, dan pematangan diri (Suparlaan Suhartono, 2009: 80).

Pada hakikatnya tujuan pendidikan adalah pembentukan kepribadian individu yang paripurna (kaffah), pribadi individu yang demikian merupakan pribadi yang mengambarkan terwujudnya keseluruhan esensi manusia secara kodrati, yaitu sebagai makhluk individu, makhluk sosial, makhluk bermoral, dan makhluk yang bartuhan (Novan Ardy Wiyani dan Barnawi, 2012 : 26).

Kewajiban dalam pendidikan yang dituntut oleh Allah kepada manusia ada dua macam; kewajiban individual dan kolektif. Macam yang pertama disebut dengan Fardlu 'Ain dan yang kedua disebut dengan Fardlu Kifāyah. Dua macam ini merupakan pembagian hukum wajib dilihat dari segi siapa yang dikenai tuntutan untuk mengerjakannya.

Perbuatan yang Fardlu 'ain adalah perbuatan yang dituntut oleh syariat kepada tiap-tiap orang mukallaf agar dikerjakan. Karena hubungan dengan Allah SWT dalam arti perhambaan terhadap-Nya merupakan titik tolak 
terwujudnya ketakwaan. Seperti melaksanakan shalat lima waktu menjadi ciri utama seorang muslim Setiap orang mukallaf dibebani perbuatan tersebut tanpa bisa digantikan oleh yang lain. Termasuk kategori perbuatan ini adalah, menunaikan zakat, berpuasa di bulan Ramadlan, dan lain semacamnya (Toto Suryana, Cecep Alba, Dkk, 2006 : 198).

Sedangkan perbuatan yang fardlu kifayah adalah perbuatan yang dituntut oleh syariat kepada orang-orang mukallaf secara kolektif. Artinya, jika ada salah seorang yang mengerjakan perbuatan tersebut, maka gugurlah kewajiban bagi yang lain. Namun, jika sama sekali tidak ada yang mengerjakan, maka berdosalah seluruhnya. Termasuk kategori perbuatan ini adalah merawat jenazah (tajhīz almayyit), melaksanakan jihad, melakukan amar makruf nahi mungkar, membangun sekolah atau rumah sakit, menjabat sebagai presiden, dan lain semacamnya.

Di tengah-tengah masyarakat masih terdapat kesenjangan saat memandang tentang kewajiban Fardu Kifayah. Sebagian orang berpandangan bahwa jika sudah ada yang mengerjakannya, maka gugurlah kewajiban semuanya. Memang pada dasarnya perbuatannya Fadhu Kifayah tapi hukum untuk mempelajari Penyelenggaraan Jenazah adalah Fardhu 'Ain yang wajib dipelajari. Dan anggapan seperti ini terjadi di sekitar kita, di kampung-kampung dan juga di kota-kota. Banyak Masyarakat yang kurang mengetahui terhadap penyelenggaraan jenazah.

Permasalahan ataupun gejala tersebut terjadi pada masyarakat Desa Sei-Petai Kec. Kampar Kiri Hilir Kab. Kampar. Kesenjangan seperti ini terjadi karena beberapa faktor; Pertama, minimnya tempat belajar tentang penyelenggaraan jenazah, Kedua, kurangnya minat masyakarat untuk mempelajari atau mengetahui hal tersebut, hal itu terlihat ketika diadakan pelatihan tentang penyelenggaraan jenazah, lebih kurang $25 \%$ masyarakat yang hadir dalam pelatihan tersebut, Ketiga, masyarakat takut untuk ikut serta dalam penyelenggaraan jenazah. Keempat, persepsi masyarakat tentang ketidakpedulian terhadap penyelenggaraan Jenazah dikarenakan sudah adanya petugas khusus yang melakukan hal tersebut. Oleh karena itulah kurangnya di kalangan masyarakat mengetahui tentang penyelenggaraan jenazah. Dari permasalahan tersebut penulis ingin mengetahui sejauh mana Pengetahuan Masyarakat Desa Sei-Petai Kec. Kampar Kiri Hilir Kab. Kampar tentang masalah penyelenggaraan jenazah.

Berdasarkan beberapa gejala di atas penulis melakukan penelitian dengan judul "Analisis Tingkat Pengetahuan Masyarakat Desa Sei-Petai Terhadap Penyelenggaraan Jenazah Kecamatan Kampar Kiri Hilir Kabupaten Kampar".

Fokus permasalahan pada penelitian ini adalah bagaimana Tingkat Pengetahuan Masyarakat Desa Sei-Petai terhadap penyelenggaraan jenazah Kec. Kampar Kiri Hilir Kab. Kampar?.

Sejalan dengan fokus masalah tersebut, maka tujuan penelitian ini adalah untuk mengetahui Tingkat Pengetahuan Masyarakat Desa Sei-Petai terhadap penyelenggaraan jenazah Kec. Kampar Kiri Hilir Kab. Kampar.

\section{KONSEP TEORI \\ Pengertian Pengetahuan}

Menurut Kamus Besar Bahasa Indonesia pengetahuan adalah ilmu (2008 : 657). Ilmu merupakan suatu kata yang sering diartikan dengan berbagai makna, atau mengandung lebih dari satu arti (Mohammad Adib, 2010 : 49).

Menurut Depdiknas pengetahuan berarti segala sesuatu yang diketahui kepandaian atau segala sesuatu yang diketahui berkenaan dengan hal mata pelajaran. Pengetahuan adalah 
merupakan hasil tahu dan ini terjadi setelah orang mengadakan pengindraan terhadap suatu objek tertentu. Pengindraaan terhadap objek terjadi melalui panca indra manusia yakni penglihat, pendengar, pencium, rasa, dan raba dengan sendiri (Notoadmodjo, 2003 :20).

Pengetahuan pada hakikatnya merupakan segenap apa yang kita ketahui tentang suatu objek tertentu, termasuk di dalamnya adalah ilmu yakni bagian dari pengetahuan yang diketahui oleh manusia, di samping berbagai pengetahuan lainnya seperti seni dan agama (Suriasumantri, 1999).

Menurut Romizowski

menjelaskan bahwa pengetahuan itu berada di dalam pikiran kita yang dapat disimpan dalam bentuk informasi. Sallis dan Jones (2002) mengatakan bahwa pengetahuan merupakan kemampuan untuk mengingat be-berapa informasi yang digunakan dengan melalui pemikiran manusia yang memberikan arti serta tujuan. Ungkapan tersebut mengandung makna bahwa pengetahuan merupakan kemampuan untuk mengetahui tem-pat, mengetahui waktu, dan mengungkapkan pendapat.

Berdasarkan beberapa pendapat di atas dapat penulis simpulkan bahwa pengetahuan itu adalah berbagai gejala yang ditemui dan diperoleh manusia melalui pengamatan inderawi. Pengetahuan muncul ketika seseorang menggunakan indera atau akal budinya untuk mengenali benda atau kejadian tertentu yang belum pernah dilihat atau dirasakan sebelumnya Pengetahuan merupakan hasil dari tahu dan ini terjadi setelah orang melakukan penginderaan terhadap suatu obyek tertentu. Penginderaan terjadi melalui panca indera manusia, yakni indera penglihatan, pendengaran, penciuman, rasa dan raba.

Pengetahuan itu sendiri dipengaruhi oleh faktor pendidikan formal. Pengetahuan sangat erat hubungannya dengan pendidikan, dimana diharapkan bahwa dengan pendidikan yang tinggi maka orang tersebut akan semakin luas pula pengetahuannya. Akan tetapi perlu ditekunkan, bukan berarti seseorang yang berpendidikan rendah mutlak berpengetahuan rendah pula. Pengetahuan seseorang tentang sesuatu objek mengandung dua aspek, yaitu aspek positif dan negatif. Kedua aspek ini yang akan menentukan sikap seseorang semakin banyak aspek pesitif dan objek yang diketahui, maka akan menimbulkan sikap makin positif terhadap objek tertentu (A. Wawan dan Dewi M, 2010 : 11).

\section{Masyarakat}

Istilah masyarakat berasal dari kata "Musyarak" yang dari Bahasa Arab yang memiliki arti ikut serta atau berpartisipasi, sedangkan dalam bahasa inggris disebut Society. Sehingga bisa dikatakan bahwa masyarakat adalah sekumpulan manusia yang berinteraksi dalam suatu hubungan sosial, mereka mempunyai kesamaan budaya, wilayah, dan identitas.

Dilihat dari konsep sosiologi masyarakat adalah sekumpulan manusia yang bertempat tinggal dalam suatu kawasan dan saling berinteraksi sesamanya untuk mencapai tujuan tertentu. Bila dilihat dari konteks pendidikan, masyarakat adalah sekumpulan banyak orang dengan berbagai ragam kualitas diri mulai dari yang tidak berpendidikan sampai kepada orang yang berpendidikan tinggi (Novan Ardy Wiyani dan Barnawi, 2012 : 87).

Manusia tidak sekadar sebagai individu yang terdiri atas jasmani dan rohani, melainkan juga sebagai makhluk sosial yang hidup bekerja sama dengan sesamanya membentuk keluarga, suku dan bangsa. Dalam kondisi sebagai makhluk sosial itulah manusia 
berkenalan satu sama lain, berhubungan, pengaruh mempengaruhi, tolong menolong dan melakukan kerja sama atas dasar kesamaan tujuan dan kesamaan derajat, membentuk kelompok atau kesatuan sosial. Kelompok sosial yang terkecil adalah keluarga yang terdiri atas suami istri dan anak-anak. Kelompok sosial berkembang dan bergabung dengan kelompok-kelompok keluarga yang lain melalui perkawinan, maka terbentuklah kelompok sosial yang lebih besar dan lebih luas menjadi suku bangsa. Himpunan dari suku-suku bangsa kemudian membentuk bangsa, misalnya Bangsa Indonesia. Kelompok yang disebut kelompok sosial dalam ilmu Sosiologi, dalam ilmu ketatanegaraan dinamakan masyarakat.

Masyarakat pada dasarnya terdiri atas dua golongan yang saling menguatkan yaitu masyarakat keluarga dan masyarakat kepentingan. Kedua golongan masyarakat itu bergabung menjadi masyarakat yang lebih besar dan bersifat nasional mengatasi masyarakat keluarga dan masyarakat kepentingan, dinamakan masyarakat umum.

Untuk itu masyarakat sebagai kelompok sosial yang saling membutuhkan antara satu dengan yang lainnya sehingga diperlukan interaksi atau hubungan yang harmonis dalam bentuk saling menghargai, menghormati, saling membantu sesama manusia untuk mencapai tujuan bersama. Demikian pula halnya dalam suatu instansi atau kantor bahwa sebagai anggota masyarakat yang kecil senantiasa menjalin hubungan kerja sama dalam memikul tanggung jawab sebagai abdi negara dan abdi masyarakat. Dikatakan abdi negara karena aparat yang bersangkutan menjalankan tugas-tugasnya dalam pemerintahan dan pembangunan di segala bidang menuju terciptanya masyarakat adil dan makmur. Aparatur negara dikatakan sebagai abdi masyarakat karena yang bersangkutan diharapkan dapat memberikan pelayanan dan perlindungan yang sebaik-baiknya kepada seluruh anggota masyarakat.

\section{Penyelenggaraan Jenazah.}

Kata jenazah, bila ditinjau dari segi bahasa (etimologis), berasal dari bahasa Arab dan menjadi turunan dari isim masdar (adjective) yang diambil dari fi'ilmadhijanaza-yajnizu-janazatan wa jinazatan. Bila huruf jim dari kata tersebut dibaca fathah (janazatan), kata ini berarti orang yang telah meninggal dunia. Namun bila huruf jim-nya dibaca kasrah, maka kata ini memiliki arti orang yang mengantuk. Lebih jauh, kata jenazah, menurut Hasan Sadiliy, memiliki makna "seseorang yang telah meninggal dunia yang sudah terputus masa kehidupannya dengan alam dunia ini" (Hasan Sadiliy, 1982: 36 ).

Dalam kamus Al-Munawwir, kata jenazah diartikan sebagai "seseorang yang telah meninggal dunia dan diletakkan dalam usungan. Kata ini bersinonim dengan al-mayyit (Arab) atau mayat (Indonesia).Karenanya, Ibn al-Faris memaknai kematian (al-mawt) sebagai peristiwa berpisahnya nyawa (ruh) dari badan (jasad) (Ahmad Warson Munawwir, 1997 : 215 ).

Dari penjelasan diatas penulis menyimpulkan pengertian dari Jenazah adalah kata lain dari mayyit ataupun seseorang yang telah berpisah antara ruh dengan jasadnya yang juga dikatakan meninggal dunia yang sudah terputus masa kehidupannya di dunia, dikatakan juga mati.

\section{Hukum penyelenggaraan jenazah.}

Hukum menyelenggarakan jenazah adalah Fardhu Kifayah, artinya apabila disuatu daerah telah ada orang yang telah menguasainya maka gugurlah kewajiban atas yang lain, namun bila disuatu daerah tidak ada yang menguasainya maka wajib atas semua orang untuk 
melaksanakannya, bila tidak ada yang melakukannya maka semua orang yang berada di daerah tersebut berdosa.

Ada beberapa kewajiban orang muslim yang hidup terhadap seseorang muslim Yang lain meninggal dunia, yang dikatakan juga dengan Fardhu Kifayah maka orang yang hidup harus menyelenggarakan 4 (empat) perkara (Sulaiman Rasyid 2011 : 164). kaum muslimin wajib mengurusi jenazah, mulai dari memandikan, mengafankan, menshalatkan, dan memakamkan (Sayyid Sabiq, 2013: 321).

\section{Memandikan Jenazah.}

Kriteria jenazah yang dimandikan.

Jenazah yang wajib dimandikan adalah a. manyat orang islam (muslim) yang tidak terbunuh oleh kaum kafir yang di sebut orang yang mati syahid dalam sebuah perperangan. Jenazahnya tidak perlu dimandikan walaupun dalam keadaan junub. Menurut mazhab malikiyah tidak perlu dimandikan. Begitu pula menurut pendapat ashah dikalangan Syafi'iyah, pendapat abu yusuf adan pendapat Muhammmad bin Hasan. Dalil pendapat ini adalah Hanzahalah mati Syahid dalam keadaan junub. Ia tidak dimandikan oleh Nabi SAW. Karena jenazah orang yang mati syahid dikafankan dengan pakaian yang di kenakannya yang patut menjadi kafan baginya. Apa bila pakaian itu kurang, maka harus disempurnakan. Dan apabila lebih dari kapan yang disunnahkan,maka dikurangi. manyat itu dikubur bersama dengan darah-darahnya. Jenazah itu tidak perlu di mandikan (Sayyid Sabiq 2013 : 322) b. Tidak karena keguguran yang usia kandungannya sebelum empat bulan (Kusen, 2011 : 8).

Dalam sebuah hadist, Rasullah SAW. Bersabdah :

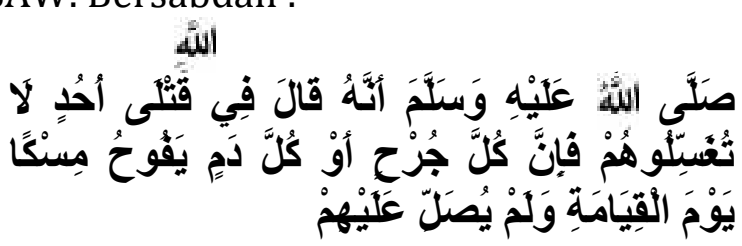

"DariJabir bin 'Abdullah ra, dari Nabi SAW, bahwasanya Nabi SAW pernah berkata mengenai syuhada' Uhud,"Jangan kalian mandikan mereka. Sebab, setiap luka dan darah akan berbau misik kelak di hari kiamat. Jenazah mereka juga tidak disholatkan."(HR. Imam Ahmad, Hadits No 14182 ).

\section{Orang yang berhak memandikan jenazah}

Orang yang berhak memandikan jenazah adalah orang yang diwasiatkan baginya. Apabila tidak ada wasiat maka yang berhak memandikan untuk laki-laki adalah bapaknya, kakeknya kebawah anak laki-lakinya, cucunya saudara kandungnya, saudara terdekat kemudian tetangganya. Untuk jenazah wanita pertama adalah ibunya, neneknya, kebawah anak perempuan, cucunya, saudara kandungnya, saudara terdekat, tetangga yang wanita. Tidak boleh jenazah laki-laki dewasa wanita yang memandikan kecuali istrinya dan sebaliknya. Untuk jenazah anak-anak dibawah tujuh tahun maka boleh memandikan laki-laki atau perempuan sebab tiada aurat baginya (Kusen, 2011 : 8).

Kalau jenazah itu laki-laki, yang memandikannya hendaklah laki-laki pula. Perempuan tidak boleh memandikan manyat/jenazah laki-laki, kecuali istri dan muhrimnya. Sebaliknya jika mnyat itu permpuan, hendaklah dimandikan oleh perempuan pula; tidak boleh laki-laki memandikan perempuan kecuali suami atau mahramnya. Jika suami dan mahram sama-sama ada, suami lebih berhak untuk memandikan istrinya. Begitu juga jika istri dan mahram sama-sama ada, maka istri lebih berhak untuk memandikan suaminya.

Bila seseorang perempuan meninggal, dan ditempat itu tidak ada perempuan, suami atau mahramnya, jenazah itu hendaklah ditayamumkan saja, tidak boleh dimandikan oleh laki-laki yang lain.. begitu juga jika meninggal 
adalah seorang laki-laki, sedangkan disana tidak ada laki-laki, istri, atau mahramnya, maka jenazah itu ditayamumkan saja. Kalau jenazah kanakkanak laki-laki, maka perempuan boleh memandikannya. Begitu juga kalau jenazah kanak-kanak perempuan, boleh pula laki-laki memandikannya. Jika ada beberapa orang yang berhak memandikan, maka yang lebih berhak adalah keluarga yang terdekat dengan jenazah, kalau ia mengetahui kewajiban mandi serta dapat dipercaya. Kalau tidak, berpindahlah hak itu kepada keluarga jauh yang berpengetahuan serta amanah (di percaya) (Sulaiman Rasyid 2011 : 167).

Para ahli fikah sepakat bahwa seorang perempuan boleh memandiakan jenazah suaminya. (Said Sabiq 2013 : 330)

Aisyah r.a berkata, "jika sejarah terulang lagi, maka tidak boleh ada yang memandikan jenazah Nabi Saw., kecuali istri-istri beliau".

Sabda Rasullah Saw :

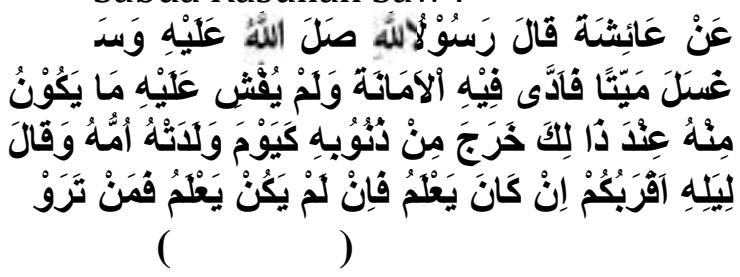

Dari aisyah. Rasullah Saw. Berkata," barang siapa memandikan jenazah dan dijaganya kepercayaan, tidak dibukakannya kepada orang lain apa-apa yang dilihat pada jenazah itu, maka bersihlah ia dari segala dosanya, seperti keadaannya sewaktu dilahirkan oleh ibunya." Kata beliau lagi," yang mengepalainya berhaklah keluarga yang terdekat kepada jenazah jika ia pandai memandikan jenazah. Jika ia tidak pandai, maka siapa saja yang di pandang berhak karena wara'nya atau karena amalannya" (Riwayat Ahmad, Hadits No 23735).

\section{Tata cara memandikan jenazah.}

Suatu prinsif dalam memandikan jenazah adalah mengguyur sekujur tubuh jenazah dengan air sekali guyuran, walaupun jenazah itu adalah orang haid atau junub. Sunnah memandikan jenazah adalah meletakkannya di tempat yang tinggi dan melepas pakaiannya. Kemudian bagian auratnya di tutupi dengan kain penutup, kecuali manyat anak kecil. Orang yang mengikuti proses pemandian jenazah hanyalah orang yang di perlukan keikut sertaannya.

Hendaklah orang yang memandikan jenazah adalah orang yang dapat dipercaya dan orang yang saleh agar menyebarkan kebaikan dilihatnya dan menyimpan keburukan dilihatnya.

Di dalam sebuah hadist Rasullah Saw bersabda, :

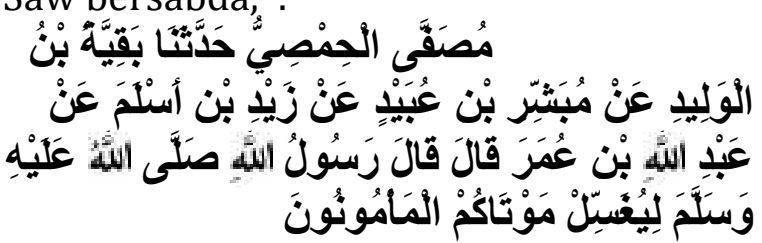

Telah menceritakan kepada kami Muhammad bin Al Mushaffa Al Himshi berkata, telah menceritakan kepada kami Baqiyyah bin Al Walid dari Mubasysyir bin Ubaid dari Zaid bin Aslam dari Abdullah bin Umar ia berkata, "Rasulullah shallallahu 'alaihi wasallam bersabda: "Yang memandikan mayat hendaknya orang-orang yang dapat dipercaya. "(HR. Ibn Majah, Hadits No 1450).

Orang yang memandikan wajib berniat untuk memandikan manyat/jenazah karena dirinya yang mendapatkan perintah memandikan. Kemudian ia memijit perut manyat secara perlahan untuk mengeluarkan najis. Ketika menyentuh aurat, tangan harus dibalut dengan kain karena menyentuh aurat adalah haram. Manyat/jenazah setelah bersih dan tidak adalah lagi kotoran pada tubuhnya lalu diwudukkan untuk shalat (Sayyid Sabiq, 2013 : 325326).

Ada beberapa tahap ataupun yang harus dipersiapkan dan tiperhatikan dalam memandikan jenazah :

1. Jenazah di hadapkan ke qiblat dan wajib tertutup antara perut dan lutut 
bagi jenazah laki-laki, sampai dada untuk jenazah perempuan.

2. Posisi kepala jenazah sedikit ditinggikan.

3. Tekanlah perutnya perlahan untuk mengeluarkan kotoran kemudian dibersikan dengan air dan kain dengan memakai sarung tangan.

4. Dibersikan dari kotoran yang melekat pada bagian tertentu seperti cat, oil/minyak dan lain-lain.

5. Membaca "bismillahirrohmanirrohim".

6. Niat memandikan jenazah, boleh di jaharkan suara niat:

7. Lafaz niat memandikan jenazah lelaki :

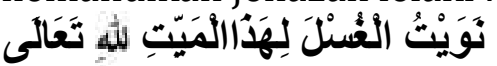

Lafaz niat memandikan jenazah perempuan :

8. Dimulai membersikan anggota tubuhnya terlebih dahulu.

9. Menyiramkan air ke seluruh anggota badannya.

10. Menggosok dimulai sebelah kanan dari mulai kepala, pundak, dada, perut tangan dan terus kebawah sampai kaki dengan memakai air bunga atau sabun dan setelah itu dilanjutkan dari sebelah kiri.

11. Kemudian membersikan punggungnya dimulai dari sebelah kanan lalu sebelah kiri.

12. Menyiramkan air bersih keseluruh badannya.

13. Di anjurkan membasuh jenazah dengan 3X, 5X, 7X dengan bilangari. ganjil sesuai dengan kebutuhan dan keadaan.

b.

14. Membersikan dua telingah, duq. alisnya, dua lubang hidungnya, giginya dengan kain sugi yang di gulung (potongan kain gulung). $\quad d$.

15. Menyiramkan air kapur atau sejenisnya.

e.

16. Mewudukkan jenazah, niat wuduk jenazah :

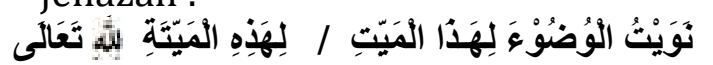

17. Mengeringkan anggota badan dengan kain bersih kemudian bersiap-siap untuk di kafani (Kusen, 2011 : 9-10).

\section{Mengkafani jenazah}

Kain kafan diambil dari harta si jenazah sendiri jika ia meninggalkan harta. Kalau ia tidak meninggalkan harta, maka kafannya menjadi kewajiban orang yang wajib memberi belanjanya ketika ia hidup. Kalau yang wajib memberi balanja itu tidak mampu, hendaklah diambil dari baitul-mal, dan di atur menurut hukum agama islam. Jika baitul-mal tidak ada atau tidak teratur, maka hal itu menjadi kewajiban muslim yang mampu. Demikian pula keperluan lainnya yang bersangkutan dengan jenazah (Sulaiman Rasyid, 2011 : 167).

\section{Kain Kafan yang di sunnahkan}

Ada beberapa kreteria kain kafan yang disunnahkan oleh Rasullah SAW :

1. Kain yang di pergunakan untuk kafan adalah kain yang bagus, bersih, menutupi.

2. Kain kafan yang berwarna putih.

3. Kain kafan sebanyak tiga lapis untuk laki-laki dan lima lapis untuk perempuan (Sayyid Sabiq, 2013 : 332).

Namun disini ada perbedaan untuk kain kafan seseorang yang sedang ikhram (Haji dan Umroh) maka kain kafannya adalah kain ikhramnya dan untuk lakilaki tidak di tutupi mukanya (Kusen, 2011 :11).

\section{Urutan tata cara mengafani}

Jenazah di ukur panjangnya dengan talinya.

Memotong lima buah tali ikatan.

Memotong kain yang diinginkan sebanyak tiga lembar. Untuk jenazah wanita ti tambah baju dan jilbab.

Lima buah ikatan ditata pada posisi kepala, dada, paha, betis, dan kaki.

Kain lebar dibentangkan di susun berlapis-lapis.

Di atasnya dikasih kapas yang disusun rapi.

Yang ditaburi dengan sesuatu yang wangi dan kapur barus. 
h. Kemudian jenazah dibaringkan diatasnya.

i. Kain yang digulung yang bagian kepala kekanan dan bagian perut ke bawah ke arah kiri atau sebaliknya.

j. Kemudian diikat dengan lima ikatan di bagian sebelah kiri tujuannya agar tidak susah saat akan di makukan ke liang lahat sebab disana tali ikatannya harus dibuka kembali (Kusen, 2011 : 11).

\section{Menshalatkan Jenazah.}

Shalat jenazah adalah shalat yang dilakukan atas jenazah secara langsung. Bila jenazah itu tidak berada di tempat di sebut shalat ghaib.

Shalat jenazaah dilakukan setelah jenazah selesai dimandikan dan dikafani. Shalat jenazah terdiri dari empat kali takbir, setelah takbir pertama dibaca surat Al-fatihah, setelah takbir kedua dibaca shalawat atas nabi dan setelah takbir ketiga dan ke empat dibaca do'a untuk jenazah untuk umat islam semuanya (Amir syarifuddin 2010 : 35).

\section{Syarat Shalat Jenazah.}

Shalat jenazah memiliki syaratsyarat seperti syarat-syarat shalat yang lain. Diantarnya adalah suci badan, suci dari hadats kecil dan hadats besar, menghadap kiblat, dan menutup aurat. Akan tetapi mengenai waktu pelaksanaan shalat, terdapat perbedaan antara shalat jenazah dan shalat lainnya. Shalat jenazah dilakukan kapan saja ketika jenazah telah siap untuk dishalatkan (Sayyid Sabiq, 2013 : 338).

Hanya tiga waktu yang tidak disukai (Makruh) Rasullah bersabda : "ada tiga waktu dimana Rasullah SAW melarang kami untuk menyolatkan atau menguburkan yang meninggal di antara kami yaitu saat matahari terbit, saat matahari di atas kepala, dan saat matahari terbenam"(HR. Abu Daud).

Menurut fatihuddin Abdul Yasin syarat-syarat shalat jenazah antara lain :

1. Jenazah sudah dimandikan dan dikafani serta siap dishalatkan.
2. Posisi jenazah didepan jama'ah.

3. Ushakan berjama'ah dengan tiga shaf kebelakang.

4. Jangan memakai sandal bila shalat diluar Masjid, tapi caranya lepas sandal itu dan injak atasnya seperti shalat diatas sejadah.

5. Harus suci dari hadats, najis, baik pakaian atau tempat seperti shalatshalat lain.

\section{Rukun Shalat Jenazah}

Posisi iman dalam melaksanakan shalat jenazah, di sebelah kepala untuk jenazah laki-laki dan di sebelah perut untuk jenazah wanita.

1. Niat Shalat Jenazah.

Niat untuk shalat jenazah laki-laki

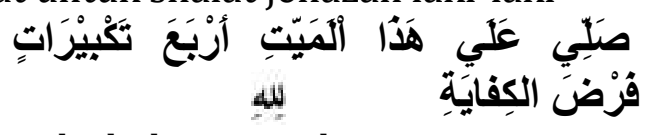

Niat untuk shalat jenazah perempuan

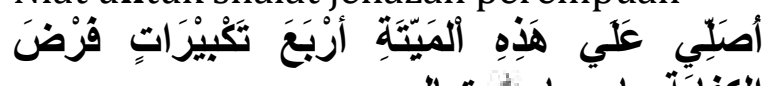

الكِفايَِةِ ماموما لله تعالِه

2. Takbir Pertama

Membaca Surat Al-fatihah

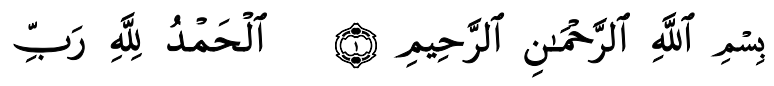

أَلَْلَمِيِتَ

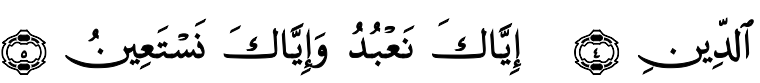

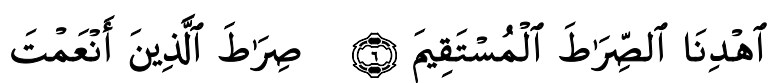

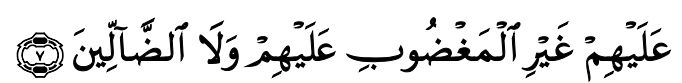

3. Takbir Kedua

Membaca Salawat Nabi

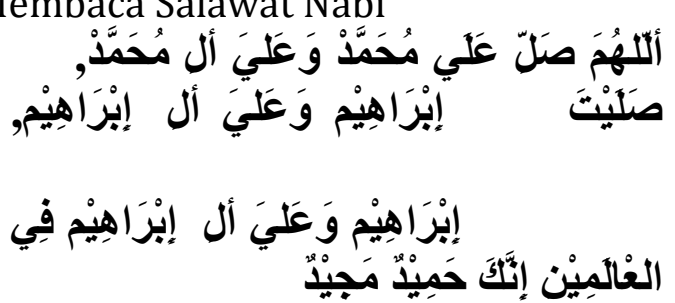

4. Takbir Ketiga

Membaca Do'a Jenazah

Doa untuk jenazah laki-laki, domirnya hu ( )

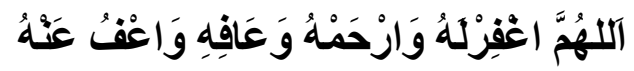


Doa untuk jenazah perempuan, domirnya (ه)

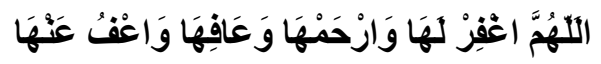

5. Takbir Ke Empat

Membaca Do'a Kedua

Doa untuk jenazah laki-laki

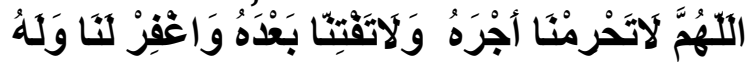

Doa Untuk Jenazah Perempuan

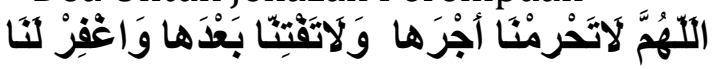

6. Salam

\section{Menguburkan Jenazah}

السَّلامُ عَلْيَكُمْ وَرَحْمَةُ اللهِ وَبَرَكَاتُهُ

(Kusen, 2011 : 18-20).

Membawa jenazah untuk dikuburkan adalah tanda memuliakannya dan hukumnya fardhu kifayah, firman Allah SWT (Q.S Al-Murosalat 25-26)

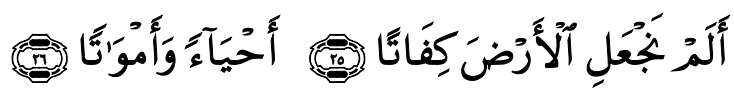

Artinya : Bukankah kami menjadikan bumi (tempat) berkumpul, Orang-orang hidup dan orang-orang mati (Q.S Al-Murosalat 25-26).

Mengusung dan menguburkan jenazah adalah khusus bagi laki-laki saja meskipun manyatnya wanita dikarenakan:

1. Sebab sudah demikian dari zaman Rasullah SAW sampai sekarang.

2. Laki-laki lebih kuat dari wanita.

3. Di kuatirkan terbuka aurat wanita di tengah orang banyak dan hal ini kurang baik. Dan yang harus menurunkan jenazah keliang kubur / lahat adalah keluarga terdekat yang laki-laki.

bukur :

Cara memasukan jenazah ke liang

1. Disunnahkan didahulukan kepalanya.

2. Bagi yang memasukan jenazah disunnahkan membaca: "Bismillahi Wa'ala Milllati Rasulillah". Rasullah SAW bersabda: "apabila menggusung ataupun memasukan jenazah kedalam kuburnya maka bacalah: Bismillahi
Wa'ala Milllati Rasulillah" (HR. Hakim).

3. Disunnahkan dimiringkan kekanan menghadap kiblat sampai mukanya menyentuh tanah.

4. Buka semua ikatan kain kafannya dan dibuka wajahnya.

5. Diganjal bawah kepala dan punggungnya dengan bantal / kepalan terbuat dari tanah.

6. Ditaruh diatas /disampingnya papan agar jenazah tidak langsung tertimbun tanah.

7. Timbunlah tanah pelan-pelan sambil di injak agar tanah lebih kuat dan padat dan tinggikan tanah kuburan dari tanah sebelumnya.

8. Disunnahkan di taruh paes dari kayu dan disiram air mawar.

9. Apabila selesai maka disunnahkan berdo'a. Sabda Rasullah SAW. "apabila Rasullah SAW telah selesai menguburkan jenazah maka beliau berdiri dan bersabda "mintahkan ampunan untuk saudaramu dan mohonkanlah ketetapan imannya karena sekarang ia sedang di tanya" (HR. Abu Daud).

\section{Konsep Operasional}

Konsep opersional adalah konsep yang digunakan untuk menjabarkan atau memberi batasan terhadap konsep teoritis. Sesuai dengan yang telah dikemukakan sebelumnya bahwa yang akan diteliti dalam penelitian ini adalah Analisis Tingkat Pengetahuan Masyarakat Desa Sei-Petai Terhadap Penyelenggaraan Jenazah, maka perlu suatu konsep operasional atau parameter, sebagai dasar berpijak. Adapun indikatornya adalah:

1. Masyarakat mengetahui yang dimaksud dengan jenazah, hukum penyelenggaraan jenazah, orang yang berhak dalam penyelenggaraan jenazah.

2. Masyarakat mengetahui kreteria jenazah yang dimandikan, orang yang 
berhak memandikan memandikan jenazah, tata cara dan langkah-langkah dalam memandikan jenazah.

3. Masyarakat mengetahui bagaimana mengafani jenazah, kain fakan yang di sunnahkan untuk jenazah, urutan tata cara mengafani jenazah.

4. Masyarakat mengetahui syarat-syarat shalat jenazah, rukun shalat jenazah.

5. Masyarakat mengetahui cara memasukkan jenazah dalam kubur.

\section{METODE}

Jenis penelitian ini adalah deskriptif kuantitatif, dengan Subjek penelitian ini adalah Masyarakat Desa Sei-Petai Kec. Kampar Kiri Hillir Kab. Kampar. Sedangkan objeknya adalah Tingkat Pengetahuan Masyarakat Desa Sei-Petai Kec. Kampar Kiri Hillir Kab. Kampar Terhadap Pengelenggaraan Jenazah. Dengan populasi penelitian berjumlah 441 orang, dan sampelnya 44 responden.

Teknik pengumpulan data dalam penelitian ini menggunakan Angket dan Dokumentasi. Sedangkan pengolahan data dilakukan dengan tahapan :

1. Editing, yakni pemeriksaan terhadap data apakah pengisian data yang salah, keliru, tidak sesuai serta tidak logis. Editing atau penyuntingan dilakukan terhadap data yang telah terkumpul melalui, angket.

2. Melakukan perhitungan (Tally) pada hasil, angket kemudian ditentukan frekuensi dan persentase dari masingmasing item pertanyaan angket yang diajukan.

3. Tabulating, yakni mentabulasikan data untuk memudahkan melakukan analisa, selanjutnya dilakukan interpretasi penafsiran untuk mencapai kesimpulan akhir penelitian (Rizal Dairi, 2008 : 104-107).

Untuk mengetahui tingkat pengetahuan Tingkat Pengetahuan Masyarakat Desa Sei-Petai terhadap Penyelenggaraan Jenazah dilakukan analisa dengan menggunakan metode analisis deskriptif kuantitatif.

$$
\mathrm{P}=\frac{I}{n} X 100 \%
$$

Keterangan:

$\mathrm{P}=$ Angka Persentase

f : Prekuensi yang sedang dicari persentasenya

n : Jumlah Frekuensi (Anas, Sudijono, 2009: 43).

Sedangkan kategori yang ditentukan untuk mengambil kesimpulan akhir dari analisisa data terhadap tingkat Pengetahuan Masyarakat Desa Sei-Petai terhadap Penyelenggaraan Jenazah yakni sebagai berikut:

1. $80 \%-100 \%$ dikategorikan Baik

2. $50 \%-79 \%$ dikategorikan Cukup Baik.

3. $0 \%-49 \%$ dikategorikan Tidak Baik.

\section{HASIL}

Desa Sungai Petai adalah merupakan daerah tempatan, yang dihuni oleh sekitar 438 Kepala keluarga yang sebagian besar adalah penduduk asli (Melayu), dan sebagian lagi ada dari suku Minang, Jawa, Sunda, Batak dan lainya.

Pada Tahun 2000 Desa Sungai Petai secara definitiv berdiri, sebelumnya Desa Sungai Petai adalah salah satu Dusun bagian dari Desa Sungai Pagar, yang saat ini sudah menjadi Kelurahan. Sejak menjadi Desa Sungai Petai sudah 3 (tiga) orang yang menjabat sebagai Kepala Desa sampai dengan saat ini. Desa Sungai Petai sekarang berada diwiayah administrasi Kecamatan Kampar Kiri Hilir Kabupaten Kampar, yang meliputi 7 Desa dan 1 Kelurahan. Kecamatan Kampar Kiri Hilir merupakan kecamatan Permekaran dari kecamatan induknya Kecamatan Kampar Kiri Kabupaten Kampar Provinsi Riau .

Pemerintahan pertama Desa Sungai Petai dipimpim oleh Kepala Desa yaitu adalah Bp. AZWAR dengan Sekretaris Desa Sdr. RUDIYANTA, periode 2014 s/d 2020 
Visi Desa :"Kemandirian dan kebersamaan dalam Membangun Demi Desa Sungai Petai Yang Lebih Maju dan adil serta Sejahtera"

Rumusan Visi tersebut merupakan suatu ungkapan dari suatu niat yang luhur untuk memperbaiki dalam Penyelenggaraan Pemerintahan dan Pelaksanaan Pembangunan di Desa Sungai Petair baik secara individu maupun kelembagaan sehingga 6 ( enam ) tahun ke depan Desa Sungai Petai mengalami suatu perubahan yang lebih baik dan peningkatan kesejahteraan masyarakat dilihat dari segi ekonomi dengan dilandasi semangat kebersamaan dalam Penyelenggaraan Pemerintahan dan Pelaksanaan Pembangunan.

\section{Misi Desa :}

1. Bersama masyarakat memperkuat kelembagaan desa yang ada

2. Bersama masyarakat dan kelembagaan desa menyelenggarakan pemerintahan dan melaksanakan pembangunan yang partisipatif.

3. Bersama masyarakat dan kelembagaan desa dalam mewujudkan Desa Sungai Petai yang aman, tentram dan damai.

4. Bersama masyarakat dan kelembagaan desa memberdayakan masyarakat untuk meningkatkan kesejahteraan masyarakat.

\begin{tabular}{|c|c|c|c|c|c|c|}
\hline NO & PERNYATAAN & TH & RG & TT & JLH & $\%$ \\
\hline & $\begin{array}{l}\text { Pengetahuan umum tentang } \\
\text { memandikan jenazah }\end{array}$ & & & & & \\
\hline 1 & $\begin{array}{l}\text { Saya mengetahui apa yang } \\
\text { dimaksud dengan jenazah }\end{array}$ & 29 & 1 & 1 & 31 & $100 \%$ \\
\hline 2 & $\begin{array}{lrr}\text { Saya } & \text { mengetahui } & \text { hukum } \\
\text { dalam } & \text { Islam } & \text { tentang } \\
\text { menyelenggarakan jenazah }\end{array}$ & 17 & 7 & 7 & 31 & $100 \%$ \\
\hline 3 & $\begin{array}{l}\text { Saya mengetahui kewajiban } \\
\text { orang yang masih hidup } \\
\text { terhadap orang yang telah } \\
\text { meninggal }\end{array}$ & 27 & 3 & 1 & 31 & $100 \%$ \\
\hline 4 & $\begin{array}{l}\text { Saya mengetahui siapa orang } \\
\text { yang paling berhak dalam }\end{array}$ & 19 & 9 & 3 & 31 & $100 \%$ \\
\hline
\end{tabular}




\begin{tabular}{|c|c|c|c|c|c|c|}
\hline & menyelenggarakan jenazah & & & & & \\
\hline 5 & $\begin{array}{l}\text { Saya mengetahui kriteria } \\
\text { jenazah yang dimandikan }\end{array}$ & 14 & 5 & 12 & 31 & $100 \%$ \\
\hline 6 & $\begin{array}{l}\text { Saya mengetahui orang yang } \\
\text { berhak memandikan jenazah }\end{array}$ & 25 & 3 & 3 & 31 & $100 \%$ \\
\hline 7 & $\begin{array}{l}\text { Saya mengetahui tata cara } \\
\text { memandikan jenazah }\end{array}$ & 7 & 14 & 10 & 31 & $100 \%$ \\
\hline 8 & $\begin{array}{lcc}\text { Saya mengetahui } & \text { niat } \\
\text { memandikan jenazah } & \\
\end{array}$ & 9 & 3 & 19 & 31 & $100 \%$ \\
\hline \multirow[t]{2}{*}{9} & $\begin{array}{l}\text { Saya mengetahui niat wudhuk } \\
\text { jenazah }\end{array}$ & 8 & 4 & 19 & 31 & $100 \%$ \\
\hline & $\begin{array}{l}\text { Pengetahuan tentang } \\
\text { mengkafani jenazah }\end{array}$ & & & & & \\
\hline 10 & $\begin{array}{l}\text { Saya mengetahui apa yang } \\
\text { dimaksud dengan mengkafani } \\
\text { jenazah }\end{array}$ & 16 & 8 & 7 & 31 & $100 \%$ \\
\hline 11 & $\begin{array}{l}\text { Saya mengetahui tata cara } \\
\text { mengkafani jenazah }\end{array}$ & 5 & 7 & 19 & 31 & $100 \%$ \\
\hline 12 & $\begin{array}{l}\text { Saya mengetahui kriteria kain } \\
\text { kafan yang disunahkan }\end{array}$ & 7 & 11 & 13 & 31 & $100 \%$ \\
\hline \multirow[t]{2}{*}{13} & $\begin{array}{l}\text { Saya mengetahui urutan tata } \\
\text { cara mengakafani jenazah }\end{array}$ & 4 & 7 & 20 & 31 & $100 \%$ \\
\hline & $\begin{array}{l}\text { Pengetahuan tentang } \\
\text { menshalatkan jenazah }\end{array}$ & & & & & \\
\hline 14 & $\begin{array}{l}\text { Saya mengetahui syarat-syarat } \\
\text { jenazah baru bisa dishalatkan }\end{array}$ & 12 & 10 & 9 & 31 & $100 \%$ \\
\hline 15 & $\begin{array}{l}\text { Saya mengetahui rukun shalat } \\
\text { jenazah }\end{array}$ & 16 & 10 & 5 & 31 & $100 \%$ \\
\hline 16 & $\begin{array}{l}\text { Saya mengetahui niat shalat } \\
\text { jenazah }\end{array}$ & 18 & 11 & 2 & 31 & $100 \%$ \\
\hline 17 & $\begin{array}{l}\text { Saya mengetahui jumlah } \\
\text { takbir pada shalat jenazah }\end{array}$ & 19 & 8 & 4 & 31 & $100 \%$ \\
\hline \multirow[t]{2}{*}{18} & $\begin{array}{l}\text { Saya mengehatui lafaz bacaan } \\
\text { pada setiap takbir dalam } \\
\text { shalat jenazah }\end{array}$ & 15 & 10 & 6 & 31 & $100 \%$ \\
\hline & $\begin{array}{l}\text { Pengetahuan tentang } \\
\text { mengubur jenazah }\end{array}$ & & & & & \\
\hline 19 & $\begin{array}{l}\text { Saya mengetahui tentang } \\
\text { galian kubur untuk jenazah }\end{array}$ & 13 & 8 & 10 & 31 & $100 \%$ \\
\hline 20 & $\begin{array}{l}\text { Saya mengetahui tata cara } \\
\text { memasukkan jenazah ke liang } \\
\text { kubur }\end{array}$ & 13 & 9 & 9 & 31 & $100 \%$ \\
\hline 21 & $\begin{array}{l}\text { Saya mengetahui orang yg } \\
\text { dibolehkan } \\
\text { memasukkan jenazah ke } \\
\text { dalam kubur }\end{array}$ & 16 & 8 & 6 & 31 & $100 \%$ \\
\hline 22 & 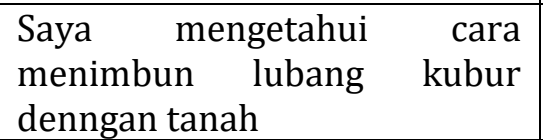 & 10 & 14 & 7 & 31 & $100 \%$ \\
\hline
\end{tabular}




\begin{tabular}{|l|l|c|c|c|c|c|}
\hline 23 & $\begin{array}{l}\text { Saya mengetahui amalan doa } \\
\text { setelah selesai menguburkan, } \\
\text { sebelum } \\
\text { kuburan }\end{array}$ & 6 & 5 & 20 & 31 & $100 \%$ \\
\hline & TOTAL & 326 & 175 & 212 & 713 & $100 \%$ \\
\hline & PERSENTASE & $45,72 \%$ & $24,54 \%$ & $29,73 \%$ & $100 \%$ & $100 \%$ \\
\hline
\end{tabular}

Berdasarkan rekapitulasi angket yang disebarkan jelas terlihat pada tabel di atas, diperoleh jumlah frekuensi jawaban "Tahu/mengetahui" (TH) sebanyak 326 responden, yang menjawab "Ragu-ragu" (RG) sebanyak 175 responden, dan yang menjawab "Tidak Tahu"(TD) sebanyak 212 responden.

Selanjutnya untuk memberikan penilaian dari tiap-tiap opsi diberi bobot sebagai berikut :
1. Tahu/mengetahui
$: 3$
2. Ragu-ragu
$: 2$
3. Tidak Tahu
$: 1$

Skor yang sudah dijumlahkan pada tabel diatas kemudian dikalikan dengan bobot masing-masing, yang menghasilkan perhitungan sebgai berikut :

$$
\begin{aligned}
& \text { (TH) Tahu/mengetahui }=326 \\
& \mathrm{x} 3=978 \\
& \text { (RG) Ragu-ragu diberi skor } \quad=175 \\
& \mathrm{x} 2=350 \\
& \text { (TT) Tidak Tahu diberi skor } \quad=212 \\
& \mathrm{x} 1=212 \\
& =1.540
\end{aligned}
$$

Hasil perhitungan tersebut kemudian diaplikasikan menggunakan rumus dibawah ini :

$$
\mathrm{P}=\frac{I}{n} \times 100 \%
$$

Keterangan:

$\mathrm{P}=$ Angka Persentase yang dicari

$\mathrm{f}=$ Banyak Frekuensi pilihan responden.

$$
\mathrm{n}=\text { Jumlah Nilai Ideal. }
$$

Nilai ideal dari pengolahan data tersebut adalah $=713 \times 3=2.139$.

$$
\text { Hasil olahan data dengan }
$$
menggunakan rumus di atas adalah sebagai berikut :

$$
\begin{aligned}
& \mathrm{P}=\frac{1.5}{2.1} \times 100 \% \\
& \mathrm{P}=71,99 \%
\end{aligned}
$$

Berdasarkan analisa terhadap rekapitulasi hasil penyajian tabel di atas dapat diketahui bahwa $\mathrm{P}=71,99 \%$, hal ini menunjukkan Tingkat Pengetahuan Masyarakat Desa Sungai Petai Kec. Kampar Kiri Hilir Kab. Kampar Terhadap Penyelenggaraan Jenazah berada pada taraf persentase $71,99 \%$ yang berada pada rentang $50 \%$ - 79\%. Dengan demikian dapat dikategorikan "Cukup Baik".

\section{SIMPULAN}

Berdasarkan penyajian dan analisa data pada bahasan sebelumnya, peneliti menyimpulkan bahwa Tingkat Pengetahuan Masyarakat Desa Sungai Petai Kec. Kampar Kiri Hilir Kab. Kampar Terhadap Penyelenggaraan Jenazah, berada pada tingkat persentase $71,99 \%$, atau berada pada rentang 50\% - 79\%, yang berarti pada kategori "Cukup Baik”.

Berkaitan dengan hasil penelitian ini, peneliti memberikan saran yaitu :

1. Untuk Masyarakat Desa Sungai Petai Kec. Kampar Kiri Hilir Kab Kampar agar meningkatkan pengetahuan dalam bidang penyelenggaraan jenazah, karena penyelenggaraan jenazah disunnahkan kepada orang yang terdekat dengan jenazah.

2. Sebaiknya dilakukan penelitian lanjutan untuk melihat perkembangan, keikut sertaan, dan kepedulian Masyarakat Desa Sei Petai Terhadap Penyelenggaraan Jenazah. 


\section{DAFTAR KEPUSTAKAAN}

Abu Bakar Muhammad, 1994, Pembinaan Manusia Dalam Islam, Surabaya: Al Ikhlas.

Ahmad Warson Munawwir, 199, Kamus Al-Munawwir, Surabaya: Pustaka Progressif.

Amir Syefuddin, 2010, Garis-Garis Besar Fikih, Jakarta: kencana prenada media group.

Anas Sudijono, 2009, Pengantar Statistik Pendidikan, Jakarta: PT.Raja Grafindo Persada.

Anton Mulyono, 2008, Kamus Besar Bahasa Indonesia, Jakarta: Balai Pustaka.

Departemen Agama RI, 1989, Qur'an Dan Terjemahaannya, Semarang: CV. Toba Putra.

Fatihuddin Abul Yasin, 200, Buku Pintar Ibadah, Surabaya: Terbit Terang.

Hadits dan terjemahan Softwer Versi II Maktabul Syamilah, Jakarta: Alhidayah, 2009.

Hasan Sadiliy, Ensiklopedi Indonesia, Jakarta: Ichtiar Baru-Van Hoere, 1982.

Hs, M., \& Hasanah, L. (2018). Tauhid: Dasar Pengembangan Kurikulum Pendidikan Islam. Al-Hikmah: Jurnal Agama Dan Ilmu Pengetahuan, 8(1), 96-112. Retrieved from http://journal.uir.ac.id/index.php/al hikmah/article/view/1543.

Kusen Ms, 2011, Panduan Tata Cara Penyelenggaraan Fardhu Kifayah, Riau : Depag,.

Lexy J. Moleong, Metodologi Penelitian Kualitatif, Bandung: Remaja Rosdakarya, 2007.

Muhammad Tholchah Hasan, Dinamika Kehidupan Religius, Jakarta: PT. Listapariska Putra, 2004.

Moenada, M. (2015). Bimbingan Konseling dalam Perspektif AlQur'an dan Al-Hadits. Al-Hikmah: Jurnal Agama Dan Ilmu Pengetahuan, 8(1), 57-72. Retrieved from http://journal.uir.ac.id/index.p hp/alhikmah/article/view/1540.

Novan Ardy Wiyani Dan Barnawi, 2012, Ilmu Pendidikan Islam, Jakarta: ArRuzz Media,.

Riduwan dan Akdon, 2009, Rumus Dan Data Dalam Analisis Statistika, Bandung: Alfabet

Rizal Dairi, 2008, Metodologi Penelitian Berbasis Kompetensi, Pekanbaru: UIR, Press,.

Sayyid Sabiq, 2013, Fikih Sunnah 2, Jakarta: Tinta Abadi Gemilang.

Suharsimi Arikunto, 2006, Prosedur Penelitian, Suatu pendekatan Praktik.Jakarta: Rineka Cipta, .

Sulaiman Rasyid, 2011, Fikih Islam , Bandung: sinar baru algensido.

Suparlan Suhartono, 2009, Filsafat Pendidikan, Jogjakarta: Ar-Rus Media,.

Syarif, M. (2017). Pelaksanaan Pendidikan Karakter dalam Pembelajaran PAI di SMK Hasanah Pekanbaru. AlThariqah: Jurnal Pendidikan Agama Islam, 1(1), 27-40. Retrieved from http://journal.uir.ac.id/index.php/a lthariqah/article/view/616.

Syarif, M. (2017). Hakekat Manusia dan Implikasinya Pada Pendidikan Islam. Al-Thariqah: Jurnal Pendidikan Agama Islam, 2(2), 135147.

Syarif, M. (2017). Penguatan Pendidikan Agama Islam (PAI) di Sekolah. Jurnal: Pigur, 2(2), 193-200.

Al-'aydarus, Syarif Muhammad. (2011). 79 Macam-Macam Shalat Sunnat, Bandung : Pustaka hidayah.

Toto Suryana, Cecep Alba, Dkk, 2006, Pendidikan Agama Islam, Bandung: Tiga Mutiara. 